\title{
Gedesentraliseerde inligtinggebruikeropleiding
}

\author{
J.C. Henning* \\ Biblioteek- en Inligtingdienste, Technikon SA, Privaatsak X90, Florida, 1710 Republiek van Suid-Afrika \\ jhenning@tsamail.trsa.ac.za
}

B.L. Oosthuizen

Departement Inligtingstudies, Randse Afrikaanse Universiteit, Posbus 524, Auckland Park, 2006 Republiek van Suid-Afrika

\begin{abstract}
Decentralised information user education. The term information user education in this article refers to all the different components of the education process that will lead to information literacy. Literature on this matter indicates that students need to be educated to become library and information literate. Distance education students also have a definite need for user education, but there are few publications on decentralised user education available. Research had to be done to develop a program for information user education for distance learners. This article reports on research that has been done on information user education in general, but also in the context of learner-centered distance education. A literature study as well as an empirical study were undertaken to determine what aspects of the training should be offered, who should present the training and what methods should be used. The results of the study as well as the recommendations that are made, are described in the article.
\end{abstract}

Die term inligtinggebruikeropleiding in hierdie artikel dui op opleiding wat al die komponente bevat om inligtinggeletterdheid te kan bewerkstellig binne en buite die biblioteek. Uit die literatuur is bepaal dat opleiding noodsaaklik is om studente biblioteek- en inligtinggeletterd te maak. Verskeie skrywers dui aan dat afstandonderrigstudente ook 'n spesifieke behoefte aan sodanige opleiding het, maar dat daar min inligting hieroor gepubliseer is. Om gedesentraliseerde inligtinggebruikeropleiding te kan ontwikkel, was dit dus noodsaaklik om navorsing oor die onderwerp te onderneem. In hierdie artikel word verslag gelewer van navorsing wat onderneem is oor inligtinggebruikeropleiding oor die algemeen, maar ook in die konteks van moderne leerdergesentreerde afstandonderrig. Die literatuurstudie word beskryf sowel as die empiriese ondersoek wat onderneem is om te bepaal watter aspekte van die opleiding aangebied moet word, wie dit moet aanbied en wat die mees geskikte metodes vir aanbieding is. Die resultate van hierdie ondersoek en die aanbevelings word beskryf.

*Outeur aan wie korrespondensie gerig moet word.

In biblioteek- en inligtingdienste wêreldwyd word ervaar dat gebruikers opleiding nodig het om inligting en inligtingdienste optimaal te kan benut (Behrens 1992:145-146; Cleveland State University 1995:1-21; Van Brakel 1975: 289; Willemse 1991:314; York 1993:1). Min navorsing is egter gedoen oor gedesentraliseerde inligtinggebruikeropleiding. Watson (1992:1) bevestig die gebrek aan gepubliseerde inligting hieroor. Deelnemers aan 'n werkwinkel oor gebruikeropleiding wat in 1996 onder leiding van Prof. $\mathrm{H}$ Rader, direkteur van die biblioteek van die Cleveland State University aangebied is, het ook aangedui dat hierdie inligting nie algemeen beskikbaar is nie.

Terselfdertyd is daar ' $n$ potensiële toename in afstandonderrigstudente. Die aanname is gebaseer op dokumentasie oor die transformasie van tersiêre onderwys in SuidAfrika. Die Nasionale Kommissie vir Hoër Onderwys wat in 1995 deur die President aangewys is se verslag oor die transformasie van tersiêre onderwys (en alle rolspelers se kommentaar daarop) vorm die basis vir die Groenskrif vir Transformasie van Tersiêre Onderwys wat in Desember 1996 gepubliseer is. Kommentaar op hierdie dokument is ingewerk in die Witskrif vir Tersiêre Onderwys wat later gepubliseer is. Dit is duidelik uit die dokumente dat tersiêre onderwys moet transformeer na 'n stelsel wat meer toeganklik is. Die aanbevelings is dat hierdie doelstelling onder andere deur middel van afstandonderrig bereik moet word (South Africa 1996:20). Afstandonderrigbiblioteke sal dus prosedures en prosesse van dienslewering moet hersien om vir die potensiële groei voorsiening te maak.

Die aanbevelings behels ook dat residensiële instellings van hulle kursusse deur middel van afstandonderrig moet aanbied. Dit bied nuwe uitdagings aan biblioteke wat tradisioneel slegs dienste vir residensiële studente aangebied het en wat nou gedesentraliseerde dienste moet lewer.

$\mathrm{Om}$ in staat te wees om 'n effektiewe program vir gedesentraliseerde inligtinggebruikeropleiding vir Technikon SA te kan ontwikkel, was dit nodig om verdere navorsing te onderneem oor die onderwerp. In hierdie artikel word verslag gedoen van die resultate van die navorsing en die aanbevelings wat genraak word. 


\section{Navorsing oor gedesentraliseerde inligtinggebrui- keropleiding}

'n Literatuurstudie is noodsaaklik geag vir die volgende redes:

- om die stand van inligtinggebruikeropleiding oor die algemeen te ondersoek;

- om die stand van inligtinggebruikeropleiding binne die konteks van afstandonderrig (nasionaal en internasionaal) te bepaal;

- om technikononderrig oor die algemeen te kan beskryf; en

- om insig te kry in die onderrrigmodel van spesifiek Technikon SA.

Aanvullend hiertoe was ' $n$ empiriese studie nodig om te bepaal:

- hoe noodsaaklik inligtinggebruikeropleiding vir Technikon SA is;

- watter aspekte in 'n program gedek behoort te word;

- op watter vlakke hierdie aspekte aangebied moet word;

- watter metodes gebruik kan word; en

- wie hierdie opleiding moet aanbied.

\section{Technikononderrig}

Om inligtinggebruikeropleiding vir Technikon SA doeltreffend te kan ontwikkel, is dit noodsaaklik om in aanmerking te neem dat technikons beroepsgerigte onderrig aanbied. Afgestudeerde studente moet oor bepaalde vaardighede beskik om onmiddellik diensbaar in 'n beroep te kan wees en hulle moet op die hoogte kan bly van vernuwings op hulle gebied. Die onderrig word koöperatief in noue samewerking met die georganiseerde handel, nywerheid en individuele werkgewers aangebied (Technikon SA 1996: 11).

\section{Onderrigmodel van Technikon SA}

Uit ondersoeke na internasionale afstandonderrigtendense, onderneem deur Technikon SA, is bevind dat moderne afstandonderrig ' $n$ metode is waarmee die beginsels van oopleerstelsels ('open learning') en fleksi-leer ('flexible learning') bereik kan word (Buitendacht 1995:3-4).

Oopleerstelsels is daarop gemik om alle struikelblokke uit die leerproses te haal deur voorsiening van:

- geleentheid tot lewenslange onderrig;

- plooibare leerproses (meerdere geleenthede vir registrasies en eksamens);

- toeganklikheid sonder geografiese struikelblokke of werkverpligtings;

- erkennings van vorige leerervarings; en

- studenteondersteuning van hoogstaande gehalte.

Fleksi-leer verwys na die gebruik van enige onderrigontwerpbenadering waarin dosente op 'n nie-tradisionele en soepele wyse daarna streef om onderrig aan te bied ter bevordering van optimale leer by studente. Dit is 'n kombinasie van:

- kontakonderrig (tydens naweke of kontakweke);
- meervoudige aanwending van onderrigtegnologie;

- die gebruik van studiemateriaal (skrifgebaseerd of in ander formate) vir kommunikasie met studente;

- 'n variasie van evalueringpraktyke aanvullend tot tradisionele afstand- of kontakonderrig (Randse Afrikaanse Universiteit 1996:2).

Verder het Technikon SA bevind dat daar drie gemeenskaplike beginsels is wat die kern van 'n goed georganiseerde afstandonderriginstelling vorm. Dit is:

- studenteondersteuning van hoogstaande gehalte;

- leerdergesentreerde studiemateriaal; en

- kwaliteit administratiewe stelsels ter ondersteuning van die ander.

Die onderrigmodel van Technikon SA, naamlik Geïntegreerde Leerdergesentreerde Afstandonderrig is hierop gebaseer en is in samewerking met die South African Institute for Distance Education ontwikkel (Buitendacht 1995:112). Die term word meestal in Engels gebruik en staan bekend as Integrated Learner Centred Distance Education (ILCDE).

\section{Gedesentraliseerde studenteondersteuning}

Hierdie ondersteuning is gebaseer op die volgende beginsels:

- dit is leerdergesentreerd;

- dit is sensitief vir veranderings in die omgewing;

- dit is sensitief vir die behoeftes van die studente; en

- dit is plooibaar.

Die stelsel bestaan uit ' $n$ sentrale kampus waar die ontwerp en ontwikkeling van die studiemateriaal gedoen word en die koördinering van die stelsel plaasvind. Dit word ondersteun deur elf streekkantore, 250 eksamensentrums en 280 gedesentraliseerde biblioteekversamelings.

\section{Leerdergesentreerde studiemateriaal}

Tydens die beplanning van die onderrigmodel is die ontwikkeling van leerdergesentreerde studiemateriaal as 'n prioriteit geïdentifiseer. Dit het gelei tot die stigting van die Sentrum vir studiepakketontwerp en -ontwikkeling. Leerdergesentreerde studiemateriaal word in projekspanne volgens die behoefte van die werkgewers en die studente ontwikkel. Hierdie projekspanne word saamgestel uit skrywers, moderatore, redigeerders, vertalers, grafiese kunstenaars, elektroniese lettersetters, didaktiese adviseurs en onderrigontwerpers. Die inligtingbibliotekarisse word betrek by die eerste ontwerpvergaderings en verskaf deurlopend inligting aan die spanne.

Die onderliggende filosofie by die beplanning van die materiaal is dat die klem op die bemeestering van die vakinhoud val en nie op memorisering nie. Hierdie doelwitte word bereik deur bepaalde leerstrategieë en leeraktiwiteite in die materiaal. Verder kan die studente deur die studiemateriaal hul sukses evalueer en hul vordering monitor. Grafiese elemente in die materiaal maak die leerproses ' $n$ 
positiewe ervaring. Hierdie tipe materiaal behoort ook met sukses vir inligtinggebruikeropleiding gebruik te kan word.

\section{Administratiewe ondersteuning}

Die stelsel is gebaseer op die ontwikkeling van ' $n$ bestuurinligtingstelsel volgens die behoeftes van die onderrigmodel. Dit behoort gedetailleerde studente-inligting, studenterekords, finansiële en administratiewe data op aanvraag te kan verskaf.

\section{Biblioteek- en inligtingdienste van Technikon SA}

Dié biblioteek het samewerkingsooreenkomste met openbare biblioteke gesluit om dienste vir studente gedesentraliseerd te kan aanbied. Tans huisves ongeveer 280 biblioteke regoor Suid-Afrika boekversamelings van Technikon SA. Technikon SA koop duplikaat kopieë van die aanbevole boeke aan, prosesseer hulle, reik hulle uit en versend hulle na openbare biblioteke. Die hoeveelheid boeke en titels vir verskillende vakke word bepaal deur die aantal studente wat vir spesifieke vakke geregistreer is in 'n bepaalde streek. Die belangrike voordeel vir die studente is dat hulle toegang het tot die dienste van bibliotekarisse wat in voeling is met die behoeftes van die gemeenskap. Toegang tot ander bronne en algemene biblioteekgebruik word so aangemoedig.

'n Posleendiens en artikeldiens is ook beskikbaar vir studente aanvullend tot hierdie dienste. Op hierdie manier het alle studente toegang tot die studiemateriaal. Pamflette met hierdie inligting word aan elke student tydens registrasie gestuur. Plakkate met inligting oor hierdie gedesentraliseerde dienste word ook aan die verskillende metropolitaanse substreke gestuur sodat dit by openbare plekke opgeplak kan word. Artikels oor die dienste word in die studentekoerant gepubliseer.

\section{Evaluering van die dienste}

Vir die doel van die ondersoek is die biblioteek- en inligtingdienste van Technikon SA geëvalueer volgens riglyne vir afstandonderrigbiblioteke en technikonbiblioteke. Die riglyne wat vir hierdie doel gebruik is, is die Australian guidelines for library and information services to external students, Canadian guidelines for library services to distance learners, Guidelines to extended library services, Association for College and Research Libraries en die riglyne van die Sertifiseringraad op Technikons (SERTEC).

Riglyne vir die bestuur, administrasie, personeelvoorsiening, fasiliteite, hulpbronne, bemarking en die onderliggende filosofie van afstandonderrigbiblioteke word in die bogenoemde literatuur gedek. Die riglyne oor die verskillende aspekte stem grootliks ooreen. Volgens hierdie evaluering en die verslag van SERTEC blyk dit dat die biblioteek- en inligtingdienste van Technikon SA oor die algemeen voldoen aan die vereistes wat gestel word. Die biblioteek behoort egter die inligtinggebruikeropleiding wat op die kampus aangebied word, uit te brei en ook te desentraliseer. Die inligting soos verskaf in die pamflette en studentekoerant bevat nie al die aspekte van inligtinggebruikeropleiding nie.

\section{Inligtinggebruikeropleiding \\ Begripverklarings}

In die literatuur word 'n verskeidenheid terme en definisies gevind wat gebruik word wanneer die opleiding van biblioteekgebruikers beskryf word. Sager (1995:50-51) gebruik die terme bibliografiese instruksie en gebruikeropleiding as sinonieme en dui aan dat dit enige en alle onderrigaktiwiteite insluit wat beplan, ontwerp en aangebied word om vaardighede van die gebruikers te verbeter om onafhanklik inligting te kan versamel en te kan organiseer. Volgens Salony (1995:31) word die terme biblioteekinstruksie, gebruikeropleiding, bibliografiese instruksie en inligtinggeletterdheid uitruilbaar gebruik wanneer daar verwys word na die onderrig van biblioteekgebruikers. Behrens (1992:26) sê dat gebruikeropleiding 'n onderrigprogram is om gebruikers met die inligtingvaardighede toe te rus wat hulle in staat stel om die bronne en fasiliteite van die biblioteek doeltreffend te kan gebruik. Van Brakel (1975:6) gebruik die term biblioteekonderrig en dui aan dat dit ten doel het om enige vorm van selfstandigheid te bewerkstellig wat die gebruiker dan van hulp sal wees om bruikbare inligtingbronne met die grootste doeltreffendheid te kan hanteer.

Behrens (1992:26) het bevind dat biblioteekvaardigheid tradisioneel die vermoë is om die dienste, bronne en fasiliteite van die biblioteek doeltreffend te kan gebruik. Dit dui op die vaardighede om inligting te kan opspoor deur byvoorbeeld die katalogus of indekse te kan gebruik. 'n Persoon wat oor hierdie vaardighede beskik is dus biblioteekgeletterd. Behrens (1992:136-137) sê dat 'n breër konsep van biblioteekvaardighede ontstaan het as gevolg van die inligtinggeletterdheidbeweging. Die moderne siening is dat die vaardigheid nie beperk is tot biblioteekgebruik nie, maar ook dui op die vaardighede om die inligting buite die biblioteek te kan opspoor en benut. Volgens Behrens (1992: 25) beskik 'n persoon oor inligtingvaardighede indien die persoon:

- weet dat inligting benodig word om probleme op te los;

- inligting kan identifiseer;

- strategieë kan bepaal om die inligting te vind;

- weet waar om die inligting te vind;

- inligting kan selekteer, analiseer, interpreteer en sistematiseer;

- inligting kan gebruik om 'n probleem op te los;

- die totale proses kan evalueer;

- saamgestelde inligting kan berg vir verwysing; en

- die oplossing en inligting kan kommunikeer.

'n Persoon wat oor hierdie vaardighede beskik is dus inligtinggeletterd. Sayed en De Jager (1997:12) stel die volgende definisie voor wat in ooreenstemming is met dié van Behrens. Inligtinggeletterdheid is die vermoë om inligting op te spoor, te gebruik en te evalueer uit verskillende 
bronne om sodoende leer te fasiliteer, probleme op te los en om nuwe inligting te skep. Die bevindings van 'n werkgroep oor inligtingvaardighede van die Cleveland State University se definisie stem ook hiermee ooreen. Die werkgroep definieer inligtinggeletterdheid opsommend soos volg: dit is die vermoë om inligting te vind, te evalueer, te gebruik en om dit in al die verskillende formate te kan kommunikeer (Cleveland State University 1995:1-21).

Hoewel die term gebruikeropleiding al die komponente van opleiding dek wat inligtinggeletterdheid kan bewerkstellig, word die term gebruiker veel eerder gekoppel aan biblioteekgebruik. Die konsep wat in hierdie ondersoek gebruik word, moet uitdrukking gee aan die ideaal om studente inligtingvaardighede aan te leer wat hulle binne en buite die biblioteek kan gebruik. As gevolg van hierdie rede word die term gebruiker gekwalifiseer deur die term inligting. Inligtinggebruikeropleiding word dus in hierdie artikel as oorkoepelende term gebruik.

\section{Ontwikkeling van inligtinggebruikeropleiding}

Van Brakel (1975: 100) het bevind dat daar sedert die veertiger jare tekens van biblioteekoriëntering en biblioteekonderrig by akademiese biblioteke was. Die ontwikkeling en groei was egter sporadies en stadig. Uitbreiding van die dienste na senior studente het eers in die sestigerjare begin.

Martin en Jacobson (1995:5-13) meen dat gebruikeropleiding in die Verenigde State nie 'n nuwe konsep is nie en dat dit so deel van biblioteekkunde is dat dit as 'n vereiste aan die dissipline gestel word. Sager (1995:49-62) sluit hierby aan en sê dat gebruikeropleiding lank reeds bestaan, maar dat dit as vakdissipline eers in die sestigerjare gevestig is.

Salony (1995:31-51) het ook bevind dat gebruikeropleiding teruggespoor kan word tot voor die Amerikaanse burgeroorlog. Deur die geskiedenis het bibliotekarisse oor die algemeen saamgestem oor die behoefte aan gebruikeropleiding. Wyses om die opleiding te verbeter, is deurentyd ondersoek. Probleme is ook ervaar met beskikbare personeeltyd.

\section{Noodsaaklikheid van inligtinggebruikeropleiding}

Van Brakel (1975:289) het bevind dat biblioteekonderrig en -oriëntering ' $n$ besliste funksie is van die naslaanafdeling van die universiteitsbiblioteek. Die groot verskeidenheid formate waarin inligting beskikbaar is en die beperkte blootstelling van studente aan bibłioteke op primêre en sekondêre onderwysvlakke is ook faktore wat die behoefte aan hierdie opleiding verhoog. Die opleiding is ook noodsaaklik vir studente wat na hul tersiêre opleiding loopbane betree, en dus voortdurend op die hoogte moet bly met resente en relevante inligting wat daagliks in groot hoeveelhede gepubliseer word.

In 'n studie onderneem deur Behrens (1992:145-146), is bevind dat gebruikeropleiding belangrik is om studente toe te rus vir voortgesette onderrig wat in die hedendaagse sa- melewing vereis word. Die doel van die opleiding is om vanaf die onderrig in biblioteekvaardighede uit te brei na ' $n$ wyer spektrum van inligtingvaardighede wat vereis word deur inligtinggeletterdheid.

In die verslag van die werkgroep oor inligtingvaardigheid, Workgroup on Information Competence in 1995, is inligtingvaardigheid uitgewys as 'n kritiese vaardigheid wat alle studente nodig het. Die werkgroep het die noodsaaklikheid van inligtingvaardigheid beklemtoon. Die groot hoeveelhede inligting wat tans beskikbaar is, verhoog hierdie behoefte. Inligting word ook vinniger beskikbaar gestel deur middel van moderne tegnologie wat gebruik word. Studente moet opgelei word om inligting self te kan opspoor ook omdat hulle relatief min inligting uit die lesings kan onthou. Al sou hulle dit tog goed onthou, verander inligting so vinnig dat dit wat tans toepaslike leerinhoude is, in die toekoms verouderd kan wees. Die werkgroep beveel ook aan dat 'n program vir inligtingvaardigheid vir afstandonderrig geloods word (Cleveland State University 1995:1-21).

York (1993:1) is van mening dat die leerproses nie net van instruksie in die klaskamer afhang nie, maar ook van die student se vermoë om inligting te kan opspoor en te kan evalueer. Een van die uitdagings van afstandonderrig is om die studente te begelei tot inligtinggeletterdheid.

Willemse (1991:314) beklemtoon die behoefte aan inligtinggebruikeropleiding by afstandonderrigstudente. Unisa se biblioteekdienste het aanvanklik aanvaar dat die studente nie die opleiding nodig het nie, aangesien die bibliotekarisse die posversoeke van studente verwerk en die bronne en inligting namens die studente herwin en aan hulle stuur. Met die toename in studentegetalle vanuit omgewings waar biblioteekdienste nie beskikbaar is nie, het die biblioteek toenemend ervaar dat die studente nie sonder hulp benodigde biblioteekmateriaal kan opspoor en gebruik nie.

\section{Invloed van inligtingtegnologie op inligtinggebrui- keropleiding}

Salony (1995:45) is van mening dat inligtingtegnologie 'n groot invloed het op die ontwikkeling van biblioteke en dit blyk dat die invloed nog groter sal word in die toekoms. Met die toename in gebruik van byvoorbeeld Internet sal die fokus op konsepte van inligtinggeletterdheid toeneem.

Rodrigues (1996:27) beklemtoon die geleenthede wat die inligtingtegnologie bied aan bibliotekarisse om gedesentraliseerde dienste en opleiding te kan aanbied. So kan 'n virtuele klaskamer vir die opleiding daargestel word en studente kan deur multimedialesse opleiding ontvang.

Wielhorski (1994:550) sê dit is reeds in die beplanning van biblioteekdienste belangrik om te bepaal hoe die gebruikers bereik kan word met behulp van inligtingtegnologie. Tradisionele gebruikergidse kan elektronies beskikbaar gestel word. By die University of Michigan is daar byvoorbeeld 'n projek wat die biblioteek en die Biblioteek- en Inligtingkunde Departement gesamentlik ontwikkel het. Vakgerigte elektroniese gidse word op die 
Wêreld-Wye-Netwerk beskikbaar gestel vir studente. Elektroniese klaskamers soos by die Steen Library by Stephen $F$ Austin State University, toegerus met interaktiewe videoen klanktoerusting kan gebruik word om die opleiding aan te bied. Kommersiële elektroniese gidse vir leeskompakskyfdatabasisse is reeds beskikbaar vir opleiding. Rekenaargesteunde onderrig kan ook gebruik word om programme volgens die behoefte van die bepaalde instelling op te stel.

\section{Stand van inligtinggebruikeropleiding by enkele afstandonderriginstellings}

Universiteit van Suid-Afrika (Unisa)

$\mathrm{Na}$ anleiding van die noodsaaklikheid van inligtinggebruikeropleiding vir studente van Unisa het die biblioteek ernstig aandag aan opleiding gegee. In 1985 is 'n pos toegewys aan die onderrig van studente in biblioteekgebruik en sedert 1986 is daar gepoog om die geskikste metodes te vind om studente in biblioteekvaardighede op te lei. Oriënteringlesings is aangebied aan studente wat die kampus as studiegroepe besoek het. Omdat een bibliotekaris nie die program aan al die studiegroepe kon bied nie, is 'n kort oudiovisuele program saamgestel. 'n Skyfieprogram van ongeveer tien minute is ook ontwikkel. Hierdie program is aan ongeveer 11000 studente gedurende 1988 en 1989 vertoon. Vir afstandonderrig is die plooibaarheid van hierdie metode baie geskik. Meerdere kopieë maak dit moontlik om die program aan verskillende groepe gelyktydig te vertoon. Dit kan ook vertoon word op tye wat die doserende personeel pas. Die aantal kykers is nie 'n probleem nie en die program kan na verskeie plekke weg van die kampus geneem word.

Gedurende 1987 is 'n werkboek deur Unisa opgestel wat aan meer as 5000 geselekteerde eerstejaarstudente gepos is. Die gebruik van die werkboek is egter gestaak aangesien daar geen eksperimentele bewys was dat dit die biblioteekvaardighede van studente bevorder het nie. Gedurende 1987 tot 1989 is werkwinkels rakende die literatuur van verskillende vakgebiede gereël tydens besoeke van studiegroepe aan die kampus. Pamflette oor 'n verskeidenheid aspekte van biblioteekgebruik is ook versprei. 'n Voorligtingstelsel met gekleurde vloerplanne en gidse tot die rakke is geïnstalleer. ' $n$ Video wat toon hoe om boeke in die studieversameling te vind, is deurentyd vertoon. Ten spyte van hierdie pogings is daar steeds gevind dat studente nie bronne kon vind wat in die biblioteek beskikbaar is nie (Willemse 1991:528).

Vanaf 1991 is die werkboeke oor biblioteekvaardighede hersien en aan die studente versprei. In samewerking met die Studentediensburo is twee radioprogramme oor biblioteekvaardighede ontwikkel. Dié programme is gedurende 1991 in Afrikaans en Engels oor Radio Unisa uitgesaai, en is getiteld Biblioteekvaardighede: voorgraadse studente en Die Honneursstudent: benutting van die biblioteek. Klankkasette van die programme kan by die biblioteek geleen word of by die universiteit gekoop word. In 1992 is die radioprogramme opgedateer en uitgesaai (Behrens 1992: 189-203).

Sedert 1991 is ' $n$ kursus in basiese biblioteek- en inligtingvaardighede ontwikkel vir studente wat die kampusbiblioteek besoek. Dié kursus word in drie oggendsessies aangebied, is vrywillig en gefokus op die behoeftes van eerstejaarstudente. 'n Sertifikaat word by suksesvolle voltooiing van die kursus aan studente uitgereik. Video- en telefoon/konferensiefasiliteite is tussen die kampus en die Kaapstad-tak en die kampus en die Durban-tak ingestel om die kursus sodoende aan meer studente beskikbaar te stel.

Sedert 1992 en 1993 is kursusse in gevorderde biblioteek- en inligtingvaardighede ontwikkel en aangebied vir studente wat die kampusbiblioteek besoek. Die kursus word in drie voldagsessies aangebied. Studente kan die kursus vrywillig bywoon met die voorwaarde dat hulle die basiese kursus suksesvol voltooi het.

Sedert 1996 word 'n kursus in basiese navorsingvaardighede angebied vir senior studente. Dié kursus is ook vrywillig met die voorwaarde dat die studente die basiese en gevorderde kursusse in biblioteek- en inligtingvaardighede suksesvol votooi het. Vir 1997 is 'n werkboek beplan wat praktiese oefeninge insluit. Die werkboek sal ook aangepas word om dit op die tuisblad van die biblioteek op die Internet beskikbaar te stel.

\section{University of Regina}

Watson (1995:21-22) dui aan dat een van die belangrikste gebruikerdienste gebruikeropleiding is. Dit lei tot die ontwikkeling van lewenslange inligtingherwinningsvaardighede. Om hierdie opleiding vir afstandonderrigstudente aan te bied, is ' $n$ uitdaging vir bibliotekarisse. Inligtingtegnologie kan gebruik word om die probleem van afstand te oorkom, mits die studente toegang het tot die tegnologie en ook weet hoe om dit te gebruik. Indien dit nie beskikbaar is nie, moet ander metodes soos gedrukte materiaal, kontaklesings, die radio en video's oorweeg word. Sy toon aan dat sommige instellings ' $n$ kombinasie van metodes gebruik. Die University of Regina het 'n video genaamd U.READ ontwikkel, wat ondersteun word deur gedrukte materiaal, gidse en beperkte kontak met die biblioteek op die hoofkampus.

Whitehead en Long (1995:171-178) verwys ook na die U.READ video en dui an dat die stap-vir-stap-gids metodes vir die ontwikkeling van soekstrategieë weergee. Die skrywers dui aan dat al hoe meer studente van afstandonderrig gebruik maak en nie altyd die hoofkampus se biblioteek kan besoek nie. Hulle het nogtans biblioteekdienste en gebruikeropleiding nodig. Dit gee aanleiding tot die vrae 'hoe moet hierdie dienste vir hulle aangebied word' en 'wie moet dit aanbied'? Die skrywers het ook bevind dat daar min publikasies is oor hierdie opleiding vir afstandonderrigstudente. Wanneer daar wel opleiding aangebied word, is dit meestal die verskaffing van indekse, 'n tolvrye telefoonnommer en ' $n$ afleweringdiens vir boeke en tydskrifte op aanvraag. Afstandonderrigstudente besoek 
dikwels nabygeleë biblioteke, maar die inligtinggebruikeropleiding vind meestal slegs by die biblioteek op die hoofkampus plaas.

\section{Genesee Community College}

Volgens Whitehead en Long (1995:171-179) ontvang die studente van die Genesee Community College in New York met welslae gebruikeropleiding by 'n nabygeleë kollege, naamlik die State University of New York College, Genessee. Samewerking tussen die twee instellings se bibliotekarisse verseker dat die aard en omvang van die opleiding dieselfde is as op die hoofkampus. Samewerking met die akademiese fakulteite verseker dat die opleiding verband hou met die kursusse. Aanvanklik is hierdie opleiding net in die Engelse kursus aangebied. Die sukses van die aanbieding het gelei tot 'n groter vraag na dieselfde opleiding in ander kursusse. Die bibliotekarisse van die State University of New York College, Genesee was bekommerd oor hul beskikbaarheid vir hul eie studente. 'n Formele ooreenkoms is gesluit tussen die twee instellings om moontlike probleme uit te skakel. Die ACRL guidelines for extended campus library services beveel ook aan dat gedetailleerde ooreenkomste tussen afstandonderriginstellings en instellings wat van hul dienste aanbied, gesluit moet word. Die skrywers het bevind dat met die formele ooreenkoms en die volgehoue entoesiasme van en samewerking tussen die akademici en die bibliotekarisse, die program tot voordeel van baie studente aangebied kan word. Hierdie program het selfversekerde studente met verbeterde biblioteekvaardighede tot gevolg.

\section{Open University}

Carty (1992:18) dui aan dat die Open University sedert 1972 gidse vir studente in gebruikeropleiding opgestel het om studente in staat te stel om onafhanklik te kan studeer en inligting te kan soek. Dit word ook gebruik om nuwe ontwikkelings bekend te stel. Die gidse bevat inligting oor die uitleg van soorte biblioteke naby die woonplekke van studente wat nuttig sal wees om te besoek, leiding in biblioteekgebruik, voorstelle vir inligtingsoektogte, lyste met bibliografiese hulpmiddels en notas oor organisasies en verenigings wat as bronne van inligting kan dien.

Vir studente wat meestersgrade in letterkunde doen, is opleiding in rekenaar-literatuursoektogte gedoen. Aanvanklik word dit op 'n toetsdatabasis en daarna op koste van die universiteit op die databasis van die biblioteek gedoen. Twee films en radioprogramme oor die gebruik van openbare en akademiese biblioteke is ontwikkel deur die BBC. Tydens die Somerskole word inligtinggebruikeropleiding soms deur die gasheeruniversiteit aangebied en soms deur aangestelde biblioteekadviseurs. Hierdie instellings ontwikkel ook pasgemaakte video- of skyfieprogramme en gidse oor biblioteekgebruik. Bywonings fluktueer na gelang van hoe belangrik die studente dit ag, of van die eise wat tutors aan hulle stel. Die openbare en akademiese biblioteke ontwikkel soms ook die opleiding vir hierdie studente. Dit word egter nie deur die universiteit gekoördineer nie.

\section{Technikon SA}

Soos bevind in die evaluering van die dienste van Technikon SA behoort die huidige opleiding van studente uitgebrei te word tot volwaardige gedesentraliseerde inligtinggebruikeropleiding. Die biblioteek bied tans slegs opleiding aan dosente, tutorbestuurders en tutors op die kampus. Opleiding word ook aangebied vir nabygeleë studente wat die biblioteek besoek en vir studente wat praktika op die kampus bywoon. Gedrukte inligtingpamflette word aan alle studente tydens registrasie beskikbaar gestel. Inligting oor die dienste word in die studentekoerant gepubliseer. Inligtinggebruikeropleiding volgens die definisie van hierdie studie word egter nog nie gedesentraliseerd aangebied nie en die mees geskikte metode hiervoor is uit die empiriese navorsing bepaal.

\section{Metodologie van empiriese studie}

Kwantitatiewe navorsing is gedoen deur middel van die opnamemetode. Die data-insameling is gedoen deur middel van 'n vraelys wat ontwikkel is met al die moontlike aspekte van inligtinggebruikeropleiding wat uit die literatuurstudie na vore gekom het.

Die populasie (454) vir die studie het bestaan uit alle rolspelers betrokke by die onderrig van, gedesentraliseerde studenteondersteuning vir, en biblioteekdienste aan die studente van Technikon SA. Dit sluit spesifiek die dosente, streekdirekteure, bibliotekarisse en tutors van Technikon $\mathrm{SA}$ in. As gevolg van die samewerkingooreenkoms met openbare biblioteke regdeur Suid-Afrika sluit die populasie ook die hoofde in van openbare biblioteke wat die versamelings van Technikon SA huisves.

Vir die studie is ' $n$ eenvoudige ewekansige steekproef geneem. Elke persoon in die populasie het dus 'n ewe groot kans gehad om in die steekproef opgeneem te word. Die groepe is alfabeties gelys en aan elke tweede persoon is ' $n$ unieke opeenvolgende nommer toegeken. Hierdie persone is in die steekproef (227) opgeneem. Na ontvangs van die vraelyste is dit sover moontlik ontfout deur telefoniese opvolging. 'n Totaal van 177 vraelyste is terugontvang wat 'n respons van $73.14 \%$ verteenwoordig. Die vraelyste is deur die Statistiese Konsultasie Dienste van die Randse Afrikaanse Universiteit verwerk en die data is op diskette geberg. Rekenaaruitdrukke is ontfout en die data is aangepas.

Die metode wat gebruik is vir die steekproefneming en die goeie responssyfer lei tot die aanname dat die response wat ontvang is verteenwoordigend van die populasie is. Verder kan daar ook kennis geneem word van die respondente se ervaring en kwalifikasies (Tabelle 1 en 2). 


\begin{tabular}{lc}
\hline $\begin{array}{l}\text { Tabel } \mathbf{1} \text { Ervaring van die res- } \\
\text { pondente in hul huidige posisies }\end{array}$ \\
\hline Ervaring & Persentasie \\
\hline 0 tot 3 jaar & $19.2 \%$ \\
3 tot 6 jaar & $24.3 \%$ \\
6 tot 9 jaar & $14.7 \%$ \\
meer as 9 jaar & $41.8 \%$ \\
\hline
\end{tabular}

\begin{tabular}{lc}
\hline Tabel 2 Hoogste kwalifikasie van respondente \\
\hline Kwalifikasie & Persentasie \\
\hline St 9 en ekwivalente of laer as st 10 & $7.3 \%$ \\
St 10 plus I of 2 jaar verdere opleiding & $4.5 \%$ \\
St 10 plus 3 of 4 jaar verdere opleiding & $34.5 \%$ \\
St 10 plus 5 of meer jare verdere opleiding & $48.6 \%$ \\
\hline
\end{tabular}

\section{Resultate van die empiriese studie}

In terme van die noodsaaklikheid van inligtinggebruikeropleiding is die volgende response ontvang (Tabelle 3 en 4).

Die respondente beveel aan dat studente van Technikon SA ' $n$ verpligte kursus in inligtinggebruikeropleiding voltooi en daarvoor krediete ontvang. Die proses om 'n kursus volgens hierdie vereistes aan te bied, sal baie lank duur en die noodsaaklikheid vir inligtinggebruikeropleiding is reeds dringend. Dit is dus wenslik om 'n kursus te ontwikkel wat aanvanklik opsioneel is en terselfdertyd 'n bewusmakingsproses van hierdie behoefte by die akademici en die Technikonbestuur te begin.

\section{Tabel 3 Noodsaaklikheid van inligtinggebruikeropleiding}

Dit is noodsaaklik om inligting te kan opspoor vir die leerproses

$100 \%$

Inligtinggebruikeropleiding is noodsaaklik om inligting te kan $100 \%$ opspoor

Inligtinggebruikeropleiding is noodsaaklik vir studente om werkopdragte te kan voltooi

Inligtinggebruikeropleiding is noodsaaklik vir studente om te kan voorberei vir eksamens

Inligtinggebruikeropleiding is noodsaaklik vir afgestudeerde $94.9 \%$ studente om op die hoogte te kan bly van 'n vakgebied

Tabel 4 Noodsaaklikheid vir inligtinggebruikersopleiding vir Technikon SA-studente

\begin{tabular}{lc}
\hline Noodsaaklik & $93.8 \%$ \\
Nie nodig nie & $6.2 \%$ \\
\hline
\end{tabular}

\section{Akademiese vlak waarop studente verskillende aspekte van inligtinggebruikeropleiding moet ont- vang}

Volgens die resultate van die respondente behoort die biblioteek- en inligtingdienste van Technikon SA die volgende aspekte vir studente tydens die eerstejaar van studie aan die Technikon aan te bied (Tabel 5).

Te oordeel aan responsresultate behoort die biblioteeken inligtingdienste van Technikon SA die volgende aspekte vir studente na die eerstejaar, maar voor-diploma/graads aan te bied (Tabel 6).

Die resultate van die respondente dui ook aan dat die biblioteek-en inligtingdienste van Technikon SA die volgende aspekte vir studente na-diploma/graads anbied (Tabel 7).

Tabel 5 Inligtinggebruikeropleiding vir eerstejaars aan Technikon SA

Oriëntering van die biblioteek- en inligtingdienste

Prosedures en regulasies van die biblioteek (verskillende stelsels wat beskikbaar is en hoe om dit te gebruik)

Elementêre beginsels van die klassifikasiestelsel (verduidelik standnommers, hoe om ' $n$ boek te vind)

Elementêre beginsels van rekenaar- of kaartkatalogusgebruik (hoe om inligting oor ' $n$ boek te vind)

Benutting van spesiale dienste (bv. fotokopiëring)

Biblioteek as instrument vir studie en navorsing

Inleiding tot naslaanwerke

Beginsels van die samestelling van 'n bibliografie

Inleiding tot inligtingbronne in verskillende formate

Inleiding tot 'n volledige operasionele inligtingdiens

Evaluering van opleiding en toekenning van sertifikate

Tabel 6 Inligtinggebruikeropleiding vir Technikon SAstudente na die eerstejaar, maar voor-diploma/graads

Uitgebreide opleiding in die klassifikasiestelsel

Opleiding in gedetailleerde doelwitte en gebruike van die rekenaar- of kaartkatalogus

Beginsels vir opstel van bibliografie

Opleiding in die gebruik van vaktydskrifte

Tegnieke van literatuursoektogte

Inleiding tot inligtingbronne in verskillende formate

Inleiding tot ' $\mathrm{n}$ volledige operasionale inligtingdiens

Evaluering van opleiding en toekenning van sertifikate 
Tabel 7 Inligtinggebruikeropleiding vir na-diploma/ graadse studente van Technikon SA

Tegnieke van literatuursoektogte

Inleiding tot inligtingbronne in verskeie formate

Inleiding tot ' $n$ volwaardige operasionele inligtingdiens

Opleiding in die gebruik van gevorderde inligtingontsluitingsapparaat

Opleiding in wetenskaplike verwysingstegniek

Evaluering van opleiding en toekenning van sertifikate

Tabel 8 Geskrewe dokumente vir inligtinggebruikeropleiding

\begin{tabular}{ll}
\hline Uiters geskik & $34.7 \%$ \\
Baie geskik & $25.1 \%$ \\
Geskik & $22.2 \%$ \\
Nie geskik nie & $13.2 \%$ \\
Gladnie geskik nie & $4.8 \%$ \\
\hline
\end{tabular}

\section{Metodes vir gedesentraliseerde inligtinggebrui- keropleiding}

Die aanbevelings van die respondente oor die verskillende metodes is soos volg (Tabel 8).

'n Belangrike aspek wat hier in aanmerking geneem moet word vir die ontwikkeling van gedesentraliseerde inligtinggebruikeropleiding vir Technikon SA is dat hierdie die enigste metode is wat alle studente kan bereik. Die infrastruktuur bestaan reeds om die materiaal aan die studente te lewer. Dit is dus wenslik dat hierdie metode eerste ontwikkel word. As deel van geïntegreerde leerdergesentreerde afstandonderrig ontwikkel Technikon SA tans interaktiewe studiemateriaal, soos vroeër beskryf. Dit is noodsaaklik om die lesingmateriaal vir inligtinggebruikeropleiding volgens hierdie metode te ontwikkel om optimale bemeestering van die materiaal te verseker.

Hierdie kan egter nie die enigste metode van gedesentraliseerde inligtinggebruikeropleiding wees nie, aangesien slegs $69.9 \%$ van hierdie repondente aangedui het dat daar

Tabel 9 Lesings oor inligtinggebruikeropleiding by studiesentrums en openbare biblioteke

\begin{tabular}{lcc}
\hline & Studiesentrums & Openbare biblioteke \\
\hline Uiters geskik & $28.7 \%$ & $26.9 \%$ \\
Baie geskik & $34.8 \%$ & $29.9 \%$ \\
Geskik & $28.1 \%$ & $24.6 \%$ \\
Nie geskik nie & $6.6 \%$ & $11.4 \%$ \\
Gladnie geskik nie & $1.8 \%$ & $7.2 \%$ \\
\hline
\end{tabular}

Tabel 10 Video- en skyfieprogramme oor inligtinggebruikeropleiding vir studente by studiesentrums en openbare biblioteke

\begin{tabular}{lcc}
\hline & Studiesentrums & Openbare biblioteke \\
\hline Uiters geskik & $31.1 \%$ & $27.5 \%$ \\
Baie geskik & $37.8 \%$ & $35.3 \%$ \\
Geskik & $25.1 \%$ & $23.4 \%$ \\
Nie geskik nie & $4.2 \%$ & $8.4 \%$ \\
Gladnie geskik nie & $1.8 \%$ & $5.4 \%$ \\
\hline
\end{tabular}

Tabel 11 Leeskompakskyf-opleidingsprogramme by studiesentrums en openbare biblioteke

\begin{tabular}{lcc}
\hline & Studiesentrums & Openbare biblioteke \\
\hline Uiters geskik & $24.6 \%$ & $21 \%$ \\
Baie geskik & $34.1 \%$ & $27.5 \%$ \\
Geskik & $28.7 \%$ & $32.3 \%$ \\
Nie geskik nie & $9 \%$ & $11.4 \%$ \\
Gladnie geskik nie & $3.6 \%$ & $7.8 \%$ \\
\hline
\end{tabular}

lesinglokale beskikbaar is by die sentrums. Technikon SA bied Help-programme as induksiekursusse vir eerstejaarstudente aan en aspekte van inligtinggebruikeropleiding soos aangedui vir eerstejaars kan hierby ingesluit word. Die voordeel hiervan is dat die program reeds gedesentraliseerd aangebied word.

Dit kan egter nie nou die enigste metode wees nie aangesien slegs $54.2 \%$ van die repondente aangedui het dat daar videospelers beskikbaar is by die sentrums, terwyl $18.1 \%$ skyfieprojektors het. Die produsering van die programme is duur, maar dit kan op verskillende tye aan groepe vertoon word en verg nie soveel addisionele personeeltyd soos byvoorbeeld die aanbied van lesings nie.

Aspekte wat in aanmerking geneem moet word is dat slegs $10.8 \%$ van hierdie repondente aangedui het dat die fasiliteite beskikbaar is by hierdie sentrums. Die produsering van die programme is duur, maar indien dit

Tabel 12 Internet-opleidingsprogramme by studiesentrums en openbare biblioteke

\begin{tabular}{lcc}
\hline & Studiesentrums & Openbare biblioteke \\
\hline Uiters geskik & $25.7 \%$ & $24 \%$ \\
Baie geskik & $28.7 \%$ & $24 \%$ \\
Geskik & $29.3 \%$ & $27.5 \%$ \\
Nie geskik nie & $9.6 \%$ & $15 \%$ \\
Gladnie geskik nie & $6.6 \%$ & $9.6 \%$ \\
\hline
\end{tabular}


gebruikervriendelik ontwerp is, kan studente dit selfstandig op hul eie tyd gebruik en verg dit nie soveel ekstra personeeltyd soos byvoorbeeld die aanbied van lesings nie.

Dit kan egter ook nie die enigste metode wees nie, aangesien slegs $6 \%$ van die repondente angedui het dat Internet by hierdie sentrums beskikbaar is. Daar is egter heelwat studente wat individueel toegang het tot Internet en dit bied geleentheid vir hierdie studente om toegang tot die inligtinggebruikeropleiding te kry. Dit is ook belangrik om in aanmerking te neem dat Technikon SA in samewerking met UNISA, Vista en Technikon Witwatersrand 'n ooreenkoms gesluit het met 'n verskaffer om Internetsentra landswyd vir die studente beskikbaar te stel.

\section{Televisie-uitsending}

Alhoewel die moontlikheid om inligtinggebruikeropleiding met televisie-uitsendings aan te bied nie in hierdie studie ondersoek is nie, behoort dit oorweeg te word. Die rede hiervoor is dat hierdie medium in 1997 vir anbieding van programme vir Technikon SA beskikbaar gestel is. Dit sal ook vir inligtinggebruikeropleiding beskikbaar wees.

\section{Aanbieders van inligtinggebruikersopleiding}

Van die respondente wat aandui dat studente van Technikon SA inligtinggebruikeropleiding moet ontvang, dui aan dat die volgende persone daarvoor verantwoordelik moet wees (Tabel 13).

\section{Probleme met afstandonderrig}

Probleme met afstandonderrig word in Tabel 14 bespreek.

\section{Stand van inligtinggebruikeropleiding by openbare biblioteke}

Die stand van inligtinggebruikeropleiding by openbare biblioteke word in Tabel 15 bespreek.

\begin{tabular}{lc}
\hline $\begin{array}{l}\text { Tabel } 13 \text { Aanbieder van inligtinggebruiker- } \\
\text { opleiding }\end{array}$ \\
\hline Bibliotekarisse van Technikon SA & $91.6 \%$ \\
Bibliotekarisse van openbare biblioteke & $64.1 \%$ \\
Tutors van Technikon SA & $58.7 \%$ \\
Dosente van Technikon SA & $29.9 \%$ \\
\hline
\end{tabular}

\section{Tabel 14 Probleme met afstandonderrig}

\begin{tabular}{lccc}
\hline Probleem & Ja & Nee & Onseker \\
\hline Ontoereikende inligtinggebruikeropleiding & $79.1 \%$ & $3.4 \%$ & $17.5 \%$ \\
Posaflewering neem lank & $68.9 \%$ & $7.9 \%$ & $23.2 \%$ \\
Bronne nie beskikbaar nie & $65 \%$ & $9.6 \%$ & $25.4 \%$ \\
Afstand na naaste biblioteek groot & $59.9 \%$ & $13 \%$ & $27.1 \%$ \\
\hline
\end{tabular}

Tabel 15 Stand van inligtinggebruikeropleiding by openbare biblioteke

\begin{tabular}{ll}
\hline Formele inligtinggebruikeropleiding & $7.8 \%$ \\
Informele inligtinggebruikeropleiding & $64.9 \%$ \\
Geen inligtinggebruikeropleiding & $27.3 \%$ \\
\hline
\end{tabular}

\section{Algemene aanbevelings}

Algemene aanbevelings van respondente is dat video's en handleidings van inligtinggebruikeropleiding aan openbare biblioteke uitgereik moet word vir inligtinggebruikeropleiding. Respondente beveel ook aan dat studiegroepe vir inligtinggebruikeropleiding gevorm moet word en dat alliansies tussen die rolspelers gevorm moet word.

\section{Samevatting}

Die onteenseglike behoefte aan inligtinggebruikeropleiding is deur die literatuurstudie, die evaluering van die biblioteek- en inligtingdienste van Technikon SA en die opname bewys. Die studie dui ook an dat hierdie opleiding ewe noodsaaklik is vir residensiële- en afstandonderriginstellings.

Ervare en kundige persone het die aspekte van inligtinggebruikeropleiding geprioritiseer. Volgens konsensus van al die rolspelers kon 'n program vir Technikon SA studente ontwikkel word.

Verder is bevind dat inligtinggebruikeropleiding die beginsels van technikononderrig ondersteun. Dit bevorder opleiding van studente wat oor bepaalde vaardighede, tegnologiese en praktykkennis moet beskik om effektiewe en produktiewe beroepsoefening te verseker, soos vereis word deur technikononderrig.

Die opleiding sluit die aanleer van biblioteek- en inligtingvaardighede in wat studente in staat stel om inligting binne en buite die biblioteek te kan opspoor en benut. Hierdie vaardighede stel die studente ook in staat om op die hoogte van 'n bepaalde vakgebied te kan bly nadat hulle afgestudeer het en vorm dus deel van die loopbaanvaardighede wat technikonstudente moet bemeester. Aanvullend hiertoe is die noodsaaklikheid van inligtinggebruikeropleiding om die leerproses te fasiliteer, studente in staat te stel om werkopdragte te kan voltooi en om te kan voorberei vir eksamens, aangedui.

Die ideaal is ten volle geïntegreerde inligtinggebruikeropleiding wat verpligtend en kredietwaardig is. Die bewusmakingsproses moet dus onmiddellik saam met die implementering van die voorgestelde program begin.

\section{Summary}

In the library and information services it has been experienced that information on decentralised information user education is not readily available. Further investigation also found that authors such as Watson (1992:1) states that not much information has been published on the topic. 
In order to develop decentralised information user education for Technikon SA it was necessary to undertake research on the subject. A literature study was essential to investigate information user education in the context of distance education (national and international), technikon education in general and the education model of Technikon SA. Additionally an empirical study was necessary to determine how essential information user education was for Technikon SA, what aspects had to be offered, at what levels these aspects had to be offered, what methods could be used and who had to present this training.

In literature a variety of terms and definitions are used to describe the education of library users. The modern view is that the skills are not limited to library use but also includes the skills to locate and utilise information outside the library. Although the term education as defined by Behrens (1992:25), Sager (1996:50-51) and Van Brakel (1976:6) covers all the components that can effect information literacy, the term user is still linked to the library. The concept used in this investigation must express the ideal of teaching students information skills they can use inside and outside the library. For this reason the term information user education is generally used.

Information for this study was obtained through quantitative research. Data collection was done by means of a questionnaire developed, based on the literature study. The population (total $=454$ ) for the study consisted of the roleplayers involved in the education of decentralised student support and library services for the students of Technikon SA. For the study a simple random sampling was done (sample $=227)$. A total of 177 questionnaires were returned representing a response of $73.14 \%$. The questionnaires were processed by the Statistical Consultation Services of the Rand Afrikaans University and the data stored on discs. Computer printouts were debugged and data adapted.

The method of sampling and the good response led to the assumption that the response received was representative of the population. Furthermore, the experience and qualifications of the respondents were noted $(41.8 \%$ have more than nine years experience in their current positions and $48.6 \%$ have a Std 10 qualification plus five or more years further training).

Most respondents (93.8\%) indicated that it is necessary for Technikon SA students to receive user education. The recommendations of the respondents for the various methods to present user education are as follows: written documents $(82 \%)$, lectures at study centres $(91.6 \%)$, lectures at public libraries $(81.4 \%)$, video and slide programmes at study centres $(94 \%)$, video and slide programmes at public libraries $(86.2 \%)$, compact disc programmes at study centres $(87.4 \%)$, compact disc programmes at public libraries $(80.8 \%)$, through Internet at study centres $(83.7 \%)$ and through Internet at public libraries $(75.5 \%)$.

The incontestable need for information user education has been proved in the literature study, the evaluation of the library and information services of Technikon SA and the survey. The study also showed that this education was equally necessary for residential and distance education institutions.

Furthermore it was found that information user education supports the principles of technikon education. It promotes the training of students who must have specific skills, technological and practical knowledge to ensure effective and productive career implementation, as demanded from technikon education. The training embraces the learning of library and information skills which will enable students to locate and utilise the information inside and outside the library. These skills also enable the students to remain up to date in a specific subject field after they have completed their studies and therefore form part of the career skills technikon students must master. In addition to this the necessity of information user education to facilitate the learning process, to enable students to complete assignments and to be able to prepare for examinations has been proved.

Decentralised student support is an important principle on integrated learner-centred distance education as offered by Technikon SA. The objectives of this principle can also be achieved through offering decentralised information user education. The study also indicated that it is advisable to develop the course material in collaboration with the Centre for Courseware Design and Development of Technikon SA. Furthermore it was indicated that this method of decentralised information user education first had to be developed since it is currently the only method that can reach all the students and because the infrastructure already exists for delivering the course material to the students. The other methods will be used alternately when the required facilities are in place.

From the survey it was determined who should be involved in the training. According to this the responsibilities of the various role-players could be determined in the study. The importance of the insight of the lecturers in the necessity of requiring information skills from the students was indicated.

The ideal is a fully intergrated information user education that is compulsory and creditworthy. The process of creating an awareness must therefore begin immediately with the implementation of the proposed programme.

\section{Erkenning}

Hierdie artikel is gebaseer op navorsing wat aan die Randse Afrikaanse Universiteit gedoen is vir die verwerwing van 'n nagraadse kwalifikasie.

\section{Verwysings}

Behrens, S.J. 1992. Undergraduate library and information skills in a distance learning environment. DPhil thesis, Pretoria, University of South Africa. 
Botha, M.A. 1995. The library as a lifeskill. TNT teaching news today: a newsletter on teaching and learning, 9(June):1-4.

Buitendach, A.J.H. 1995. Integrated learner centred distance education: TSA's winning asset for the RDP. Roodepoort: Technikon SA.

Carty, J. 1991. Library services for distance education students: adequacy of provision: the Open University, Australian and Canada. MLib dissertation, Aberyswyth, University Colleges of Wales.

Cleveland State University. Commission on Learning Resources and Instructional Technology. 1995. Information competence in the CSU: a report. Cleveland: Cleveland University.

Martin, L.M. \& Jacobson, T.E. 1995. Reflection on maturity: introduction to 'library instruction revisited: bibliographic instruction comes of age, in Martin, L.M. ed. Library instruction revisited: bibliographic instruction comes of age. New York: Haworth Press: 5-13.

Randse Afrikaanse Universiteit. 1996. Konsepverslag van die Van der Merwe-kommissie oor buigsame en geïntegreerde universiteitsonderrigmodelle in Australië. Johannesburg: RAU.

Rodriques, H.F. 1996. The role of the library in distance education. Microcomputers for information management: global internetworking for libraries, 13(1):21-30.

Sager, H. 1995. Implications for bibliographic instruction, in The impact of emerging technologies on reference service and bibliographic instruction. Westport, Conn.: Greenwood Press:4962.

Salony, M.F. 1995. The history of bibliographic instruction: changing trends from books to the electronic world, in Martin, L.M. ed. Library instruction revisited: bibliographic instruction comes of age, New York: Haworth Press:31-51.
Sayed, Y. \& De Jager, K. 1997. Towards an investigation of information literacy in South African students. South African journal of library and information science, 65(1):5-21.

South Africa. 1996. Department of Education. Green paper on higher education transformation. Pretoria: Government Printer.

Technikon SA. 1996. Bemarking: jaarboek 1997. Roodepoort: Technikon SA.

Van Brakel, P.A. 1975. Biblioteekoriëntering en -onderrig aan universiteitstudente: 'n kritiese evaluering van die huidige situasie in enkele lande, met spesiale verwysing na die Republiek van Suid-Afrika. MBibl-verhandeling, Bloemfontein, Universiteit van die Oranje-Vrystaat.

Watson, E. 1992. Library services to distance learners: a report. Barbados: University of the West Indies.

Watson. E. 1995. Distance librarianship: a perspective. Barbados: University of the West Indies.

Wielhorski, K. 1994. Teaching remote users how to use electronic information resources. The public access computer systems review, 5(4):5-20.

Willemse, J. 1991. University library service dedicated to distance teaching: the University of South Africa experience. Library trends, 39(4):514-534.

Whitehead, A. \& Long, M.M. 1995. Providing off-campus bibliographic instruction: when off-campus means someone else's campus, in Martin, L.M. ed. Library instruction revisited: bibliographic instruction comes of age, New York: Haworth Press:171-180

York, V. 1993. A guide for planning library integration into distance education programmes. Boulder: Western Interstate Commission for Higher Education. 